\title{
Russian eruption warning systems for aviation
}

\author{
Christina Neal · Olga Girina · Sergey Senyukov • Alexander Rybin · \\ Jeffrey Osiensky $\cdot$ Pavel Izbekov $\cdot$ Gail Ferguson
}

Received: 7 November 2007 / Accepted: 9 January 2009/Published online: 12 February 2009

(C) Springer Science+Business Media B.V. 2009

\begin{abstract}
More than 65 potentially active volcanoes on the Kamchatka Peninsula and the Kurile Islands pose a substantial threat to aircraft on the Northern Pacific (NOPAC), Russian Trans-East (RTE), and Pacific Organized Track System (PACOTS) air routes. The Kamchatka Volcanic Eruption Response Team (KVERT) monitors and reports on volcanic hazards to aviation for Kamchatka and the north Kuriles. KVERT scientists utilize real-time seismic data, daily satellite views of the region, real-time video, and pilot and field reports of activity to track and alert the aviation industry of hazardous activity. Most Kurile Island volcanoes are monitored by the Sakhalin Volcanic Eruption Response Team (SVERT) based in Yuzhno-Sakhalinsk. SVERT uses daily moderate resolution imaging spectroradiometer (MODIS) satellite images to look for volcanic activity along this 1,250-km chain of islands. Neither operation is staffed $24 \mathrm{~h}$ per day. In addition, the vast majority of Russian volcanoes are not monitored seismically in real-time. Other challenges include multiple time-zones and language differences that hamper communication among volcanologists and
\end{abstract}

C. Neal $(\bowtie)$

U.S. Geological Survey, Alaska Science Center, Alaska Volcano Observatory, 4210 University Drive,

Anchorage, AK, USA

e-mail: tneal@usgs.gov

O. Girina

Institute of Volcanology and Seismology, Petropavlovsk-Kamchatsky, Russia

S. Senyukov

Kamchatka Branch of Geophysical Survey, Petropavlovsk-Kamchatsky, Russia

A. Rybin

Institute of Marine Geology and Geophysics, Yuzhno-Sakhalinsk, Russia

J. Osiensky

NOAA National Weather Service, Anchorage, AK, USA

P. Izbekov

University of Alaska Geophysical Institute, AVO, Fairbanks, AK, USA

G. Ferguson

Federal Aviation Administration, Anchorage ARTCC, Anchorage, AK, USA 
meteorologists in the US, Japan, and Russia who share the responsibility to issue official warnings. Rapid, consistent verification of explosive eruptions and determination of cloud heights remain significant technical challenges. Despite these difficulties, in more than a decade of frequent eruptive activity in Kamchatka and the northern Kuriles, no damaging encounters with volcanic ash from Russian eruptions have been recorded.

Keywords Volcanic ash and aircraft safety - Kamchatka volcanoes .

Kurile volcanoes · Ash clouds · Volcano hazard warnings · Volcano hazards ·

Aviation safety

\section{Abbreviations}

$\begin{array}{ll}\text { ARTCC } & \text { Air Route Traffic Control Center } \\ \text { ASTER } & \text { Advanced Spaceborne Thermal Emission and Reflection Radiometer } \\ \text { AVHRR } & \text { Advanced Very High Resolution Radiometer } \\ \text { AVO } & \text { Alaska Volcano Observatory } \\ \text { CWSU } & \text { Center Weather Service Unit } \\ \text { FIR } & \text { Flight Information Region } \\ \text { IATA } & \text { International Air Transport Association } \\ \text { ICAO } & \text { International Civil Aviation Organization } \\ \text { KVERT } & \text { Kamchatka Volcanic Eruption Response Team } \\ \text { MIS } & \text { Meteorological Impact Statement } \\ \text { MTSAT } & \text { Multi-Functional Transport Satellite } \\ \text { MWO } & \text { Meteorological Watch Office } \\ \text { MODIS } & \text { Moderate Resolution Imagine Spectrometer } \\ \text { NOPAC } & \text { North Pacific } \\ \text { NOTAM } & \text { Notice to Airmen } \\ \text { OMI } & \text { Ozone Monitoring Instrument } \\ \text { PACOTS } & \text { Pacific Organized Track System } \\ \text { RTE } & \text { Russian Trans East (air routes) } \\ \text { RACGAT } & \text { Russian American Coordinating Group for Air Traffic } \\ \text { SIGMET } & \text { Significant Meteorological Information } \\ \text { SVERT } & \text { Sakhalin Volcanic Eruption Response Team } \\ \text { TFR } & \text { Temporary Flight Restriction } \\ \text { USGS } & \text { US Geological Survey } \\ \text { UUA } & \text { Urgent Pilot Report } \\ \text { VAA } & \text { Volcanic Ash Advisory } \\ \text { VAAC } & \text { Volcanic Ash Advisory Center } \\ & \end{array}$

\section{Introduction}

Commercial air transport in the Northern Pacific constitutes one of the world's busiest passenger and cargo markets (Airbus 2008). At the end of 2007, more than 200 flights per day travel over or immediately down wind of Russian volcanoes (Fig. 1). The high volume of traffic and few alternate airports over this vast oceanic terrain amplify the risk of an encounter with volcanic ash that could lead to in-flight engine failure and other damage to aircraft systems. The development of two volcanos monitoring and reporting scientific organizations in the Russian Far East has significantly mitigated this risk. As evidence, 


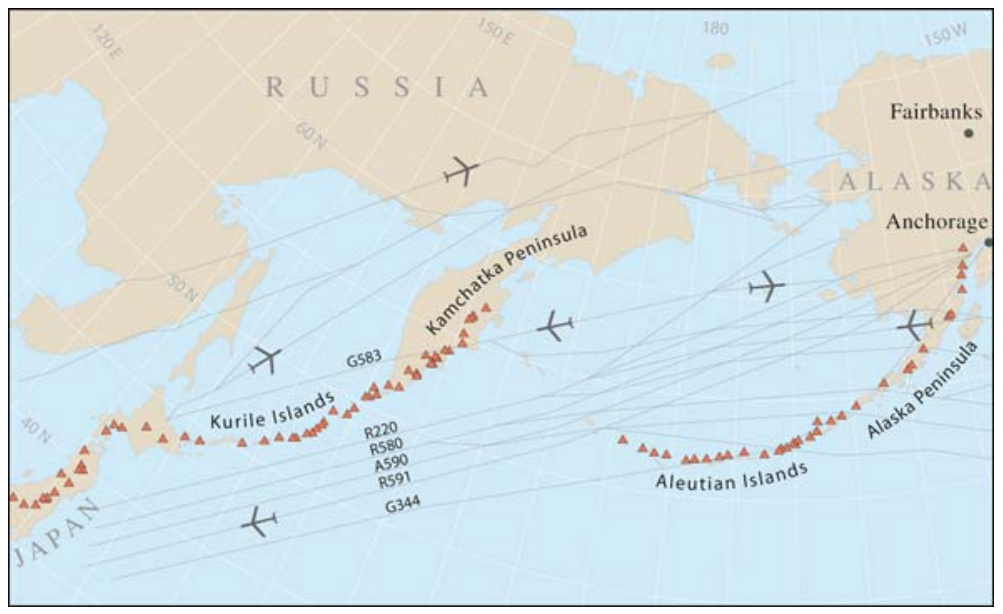

Fig. 1 Schematic portrayal of principal flight routes in the Northern Pacific region. Red triangles are potentially active volcanoes. The NOPAC consists of five labeled fixed tracks and nine transition routes from Alaskan airspace to destinations in Asia. G583 is a principal Russian Trans East (RTE) route. The two northerly NOPAC routes (R220 and R580) are westbound only primarily to avoid the normal jet stream position. A590 is eastbound only. R591 and G344 are bidirectional depending on the location of the Pacific Organized Track System (PACOTS), time of day, and traffic load. The PACOTS tracks (not shown) are routes that connect the west coast of the US and the NOPAC. These "flextracks" are generated daily based on winds. Depending on how far north PACOTS tracks are located, many additional aircraft could be at risk of an ash cloud encounter

despite the rapid growth in air traffic during a time of frequent Russian eruptions over the past 15 years, to our knowledge, no damaging encounters with volcanic ash from Russian volcanoes have occurred (IAVWOG 2008; Neal 2003).

This paper reviews the current status of technical volcano monitoring and operational Russian eruption warnings geared toward aviation interests in the Northern Pacific. Although the impacts of Russian eruptions can extend thousands of kilometers downwind for the largest of events, here we consider this region to include Canadian, US, Russian, and Japanese airspace adjacent and immediately downwind of the Kurile, Kamchatka, and Alaskan volcanoes. We discuss interconnected roles and responsibilities among entities from three countries, all which have key roles in the warning process, and highlight important ongoing challenges.

\section{Kamchatkan Volcanic Eruption Response Team (KVERT)}

Following several dangerous encounters between aircraft and ash in the late 1980s and early 1990s (Miller and Casadevall 2000), the US Geological Survey (USGS) and its cooperators recognized the need to expand volcano monitoring and eruption reporting to include the highly active and explosive volcanoes of Kamchatka (Fig. 2). Russian scientists had long conducted scientific investigations and seismic monitoring of many Kamchatkan volcanoes, however, reliable and consistent English-language eruption reporting mechanisms geared for the aviation industry did not exist. In 1993, USGS and Russian volcanology counterparts in the Institute of Volcanic Geology and Geochemistry (IVGG) and the Kamchatka Experimental and Methodical Seismological Department 


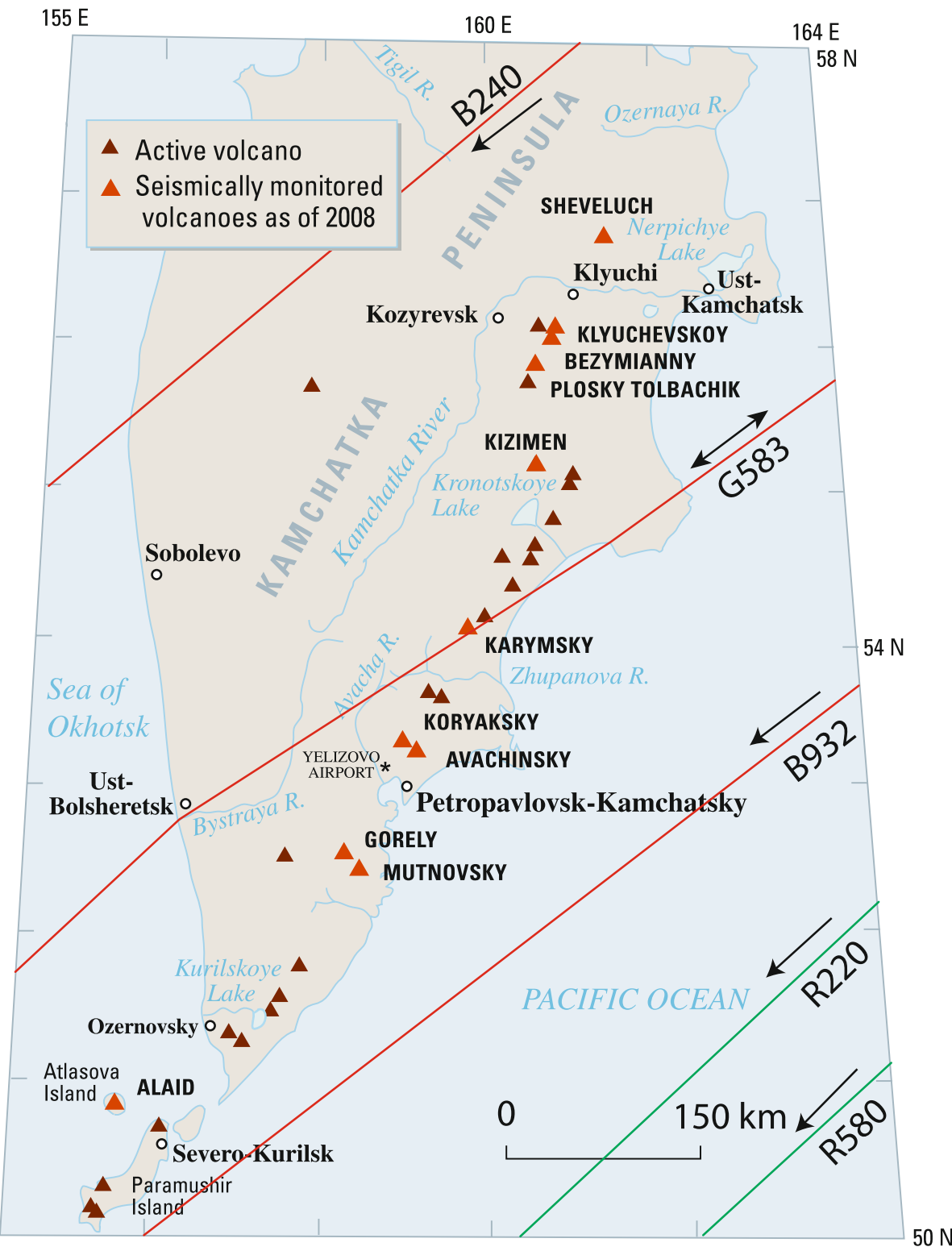

Fig. 2 Map of Kamchatkan volcanoes and schematic representation of principal NOPAC (green) and RTE (red) air routes in the immediate vicinity of the Peninsula. G583 is bi-directional. B240, B932, R220, and R580 are westbound only. As of late 2007, B932 is still considered a demonstration route. B240 opened in October 2007 and is expected to receive significant traffic loads

(KEMSD) established the KVERT project (Kirianov et al. 2002). IVGG and KEMSD were scientific research organizations within the Russian Academy of Science, and both organizations contributed staff who worked part-time on KVERT-related monitoring and reporting duties. IVGG members of KVERT were volcanologists familiar with 
Kamchatka's volcanoes and able to prepare English-language alerts regarding volcanic activity. KEMSD's research laboratory of seismic and volcanic activity hosted volcano seismologists who maintained seismic networks, conducted daily data analysis and, in addition to other duties and geophysical research programs, collaborated with IVGG staff to issue volcanic activity forecasts and interpretive statements.

The first year of KVERT operation saw major eruptions from Klyuchevskoy in 1994 (Miller and Casadevall 2000) and Bezymianny in 1995 (McGimsey and Neal 1996). Both eruptions produced significant ash clouds that reached $10 \mathrm{~km}$ in altitude or more and stretched for more than $1,000 \mathrm{~km}$ across air routes of the North Pacific significantly disrupting flights. The Klyuchevskoy eruption resulted in a single, non-damaging aircraft-ash encounter, the only encounter on record for Russian eruptions (IAVWOG 2008). Sheveluch, Klyuchevskoy, Bezymianny, and Karymsky volcanoes remained frequently active for the first decade of KVERT's operation. The lack of further incidents demonstrated the effectiveness of increasingly close cooperation and communication among Russian and US aviation, meteorology, and volcanology partners.

In 2004, IVGG merged with another scientific group, the Institute of Volcanology, to form a single Institute of Volcanology and Seismology (IVS). KEMSD was renamed the Kamchatka Branch of Geophysical Surveys (KBGS). By this time, KBGS had developed a capability to process and analyze NOAA Advanced Very High Resolution Radiometer (AVHRR) satellite images received from the Kamchatkan Center for Communications and Monitoring. This provided an important complement to its seismic monitoring and now KBGS seismic analysts scan AVHRR imagery each day to look for thermal anomalies or evidence of ash. They compare brightness temperature data of optically opaque ash clouds in suitable images to atmospheric profiles in order to estimate the altitude of ash cloud tops. In 2004, IVS scientists in KVERT began to receive raster Moderate Resolution Imaging Spectrometer (MODIS) images from NASA satellites processed by colleagues at DalInformGeoCenter of the Ministry of Natural Resources of Russia. By 2007, IVS had arranged to receive its own AVHRR and MODIS data feed from a different source in Russia, and IVS KVERT staff routinely examined satellite data for evidence of volcanic activity. IVS KVERT staff also receives and processes NASA-Japanese Ministry of Economy, Trade, and Industry (METI) Advanced Spaceborne Thermal Emission and Reflection Radiometer (ASTER; Yamaguchi et al. 1998; Gillespie et al. 2005) and Ozone Monitoring Instrument (OMI; Levelt et al. 2006) data on occasion to examine high-resolution thermal and sulfurdioxide signals related to Kamchatkan volcanic activity.

The backbone of volcano monitoring in Russia is the network of about 30 real-time seismometers installed and maintained by KBGS in close proximity to 10 of the nearly 30 active volcanoes in Kamchatka and Alaid Volcano on Atlasova Island (Fig. 2). An 11th volcano, Kizimen, is minimally monitored by a single seismic station located $20 \mathrm{~km}$ from the volcanic cone. All seismic data are evaluated daily to characterize activity at each volcano (Fig. 3). KBGS also maintains three web-cameras from continuously staffed seismic stations near Klyuchevskoy, Bezymianny, and Sheveluch volcanoes (Fig. 4). These images and the on-line video generation capability have proven extremely useful to operational users and aviation concerns around the world.

Presently, KVERT consists of about five scientists from IVS and about five scientists from KBGS, all located in Petropavlovsk-Kamchatsky. Students in volcanology and related disciplines from Kamchatka State University are occasionally employed by KVERT. IVS staff on Paramushir Island reports periodic observations of Ebeko and Chikurachki volcanoes. IVS and KBGS field station scientists in settlements near Klyuchevskoy and Sheveluch volcanoes provide reliable, expert sources of ground-observations 


\begin{tabular}{|c|c|c|c|}
\hline Volcanoes & Seismicity & Visual data & Satellite data \\
\hline Sheveluch & $\begin{array}{l}\text { Above background levels. } \\
\sim 165 \text { seismic events into the edifice of the volcano. } \\
\text { Shallow events, indicating possible ash-gas explosions up } \\
\text { to } 5000 \mathrm{~m} \text { ASL or avalanches. } \\
\text { Weak intermittent spasmodic volcanic tremor. } \\
04: 37 \text { - shallow event, indicating possible ash-gas } \\
\text { explosion } \sim 6500 \mathrm{~m} \text { ASL or avalanche, then height of ash } \\
\text { cloud was less than } \sim 6500 \mathrm{~m} \text {. } \\
20: 50-\text { series shallow events, indicating possible ash-gas } \\
\text { explosions } \sim 6500 \mathrm{~m}-10000 \mathrm{v} \text { ASL or avalanches, then } \\
\text { height of ash cloud was less than } \sim 6500 \mathrm{~m}-10000 \mathrm{~m} \text {. }\end{array}$ & $\begin{array}{l}\text { 04:00 obscured. } \\
\text { 20:00 obscured. }\end{array}$ & $\begin{array}{l}\text { Thermal anomaly: NOAA17: } \\
09: 23 \text { - } 4 \text { pixels through the } \\
\text { clouds, peak reading of }(20.2 \\
\text { C), background of }(-10 \mathrm{C}) .\end{array}$ \\
\hline Klyuchevskoy & $\begin{array}{l}\text { At background levels. } \\
\text { Weak seismic events into the edifice of the volcano. } \\
\text { Weak continuous spasmodic volcanic tremor. }\end{array}$ & $\begin{array}{l}\text { 04:00 obscured. } \\
\text { 20:00 obscured. }\end{array}$ & $\begin{array}{l}\text { No thermal anomaly observed. } \\
\text { Obscured by clouds. }\end{array}$ \\
\hline Bezymianny & $\begin{array}{l}\text { Slightly above background levels. } \\
\text { EQs: } 1-\mathrm{Ml} \geq 1.25 \text {. } \\
06: 00-23: 00 \text { no data }\end{array}$ & $\begin{array}{l}\text { 07:00 obscured. } \\
\text { 20:30 obscured. }\end{array}$ & $\begin{array}{l}\text { No thermal anomaly observed. } \\
\text { Obscured by clouds. }\end{array}$ \\
\hline $\begin{array}{l}\text { Plosky } \\
\text { Tolbachik }\end{array}$ & $\begin{array}{l}\text { No detectable seismicity. } \\
06: 00-23: 00 \text { no data }\end{array}$ & $\begin{array}{l}\text { 07:00 quiet } \\
20: 30 \text { obscured. }\end{array}$ & $\begin{array}{l}\text { No thermal anomaly observed. } \\
\text { Obscured by clouds. }\end{array}$ \\
\hline Kizimen & $\begin{array}{l}\text { No detectable seismicity. } \\
06: 00-23: 00 \text { no data }\end{array}$ & No data. & $\begin{array}{l}\text { No thermal anomaly observed. } \\
\text { Obscured by clouds. }\end{array}$ \\
\hline Karymsky & $\begin{array}{l}\text { Above background levels. } \\
\sim 500 \text { weak local shallow Eqs. } \\
\text { Intermittent spasmodic volcanic tremor. } \\
\text { Possible weak ash-gas explosions and avalanches. } \\
05: 12 ; 03: 20 \text { - shallow events, indicating possible ash-gas } \\
\text { explosions } \sim 2300 \mathrm{~m} \text { and } 2900 \mathrm{ASL} \text { accordingly and } \\
\text { avalanches. }\end{array}$ & No data. & $\begin{array}{l}\text { No thermal anomaly observed. } \\
\text { Obscured by clouds. }\end{array}$ \\
\hline Koryaksky & No detectable seismicity. & $\begin{array}{l}\text { 05:00 quiet. } \\
\text { 20:00 quiet. }\end{array}$ & No thermal anomaly observed. \\
\hline Avachinsky & At background levels. & $\begin{array}{l}\text { 05:00 quiet. } \\
\text { 20:00 quiet. }\end{array}$ & No thermal anomaly observed. \\
\hline Gorely & $\begin{array}{l}\text { 05:00 quiet. } \\
\text { 20:00 quiet. }\end{array}$ & & No thermal anomaly observed. \\
\hline Mutnovsky & $\begin{array}{l}\text { Slightly above background levels } \\
\text { Weak continuous spasmodic volcanic tremor. }\end{array}$ & $\begin{array}{l}\text { 05:00 quiet. } \\
\text { 20:00 quiet. }\end{array}$ & No thermal anomaly observed. \\
\hline Alaid & At background levels. & No data. & No thermal anomaly observed. \\
\hline
\end{tabular}

Fig. 3 Sample of a daily summary of seismic, AVHRR satellite, and web camera (video) observations and data for Kamchatkan volcanoes. These summaries are prepared by scientists of KBGS and emailed to many operational users each day

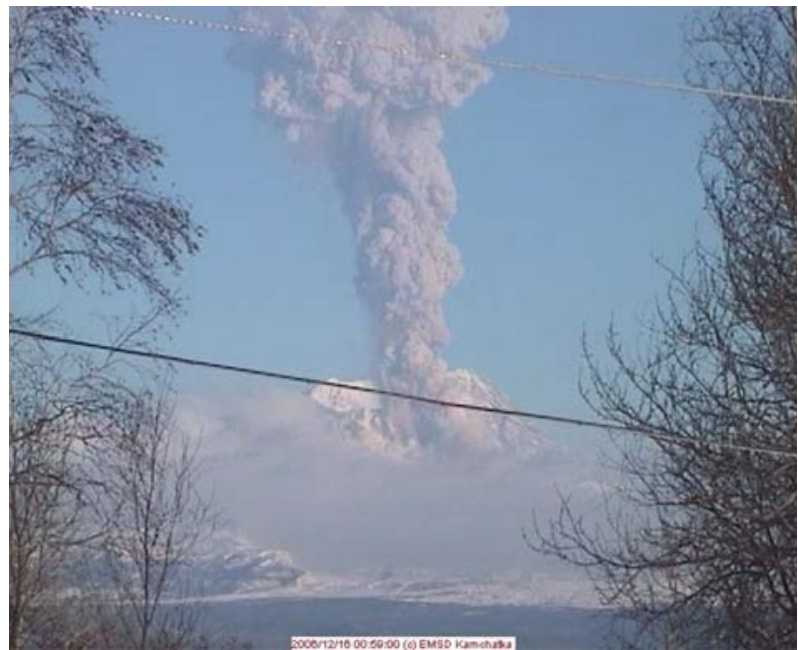

Fig. 4 Sample image form a KBGS web camera located in the community of Klyuchi, $\sim 46 \mathrm{~km}$ south of Sheveluch Volcano. In this image, a towering column of ash rises from the Sheveluch lava dome. KVERT scientists use these data during clear weather to track activity and to estimate plume height and composition (e.g. ash or gas/steam only). For volcanoes with frequent explosive activity such as Sheveluch, KBGS has also used plume height data from web camera imagery to calibrate the correlative seismic signal. This can then be applied at night and in bad weather to estimate possible plume heights 
and photographs. Although reachable by cell phone, KVERT is not routinely staffed $24 \mathrm{~h}$ per day.

In the early days of KVERT, an eruption in Kamchatka would prompt a fax or phone call to the Alaska volcano observatory (AVO) in Anchorage, Alaska, who in turn would rebroadcast a facsimile to a list of aviation users and notify key government agencies by telephone. Now, more than 300 users including US aviation and meteorological authorities receive email notification directly from KVERT and KBGS. AVO continues to re-broadcast formal KVERT information releases by facsimile and these notices are also posted on the AVO web site. Additionally, AVO notifies key government agencies in the US and Canada following significant volcanic events in Russia. By 2006, KVERT's web page hosted timely English-language text messages and photographs of current activity. KVERT also shares a weekly summary of volcanic activity in Kamchatka with Kamchatkaeronavigatsia, the local aviation authority.

In the event of an eruption or change in a volcano's status or color code, KVERT IVS staff shares information domestically via telephone, first notifying the Meteorological Watch Office (MWO) at Yelizovo Airport. The MWO is then responsible for contacting air traffic control in Petropavlovsk which is also located at Yelizovo Airport. Subsequent Significant Meteorological Information (SIGMET) distribution by the MWO via the Aeronautical Fixed Telecommunication Network has improved over the years, and SIGMETs are now issued promptly following most reports of ash producing events in Kamchatka. Urgent email messages describing unrest or actual eruptions are sent by both IVS and KBGS staff of KVERT to the Tokyo and Anchorage Volcanic Ash Advisory Centers (VAACs), AVO staff and duty scientists, the Center Weather Service Unit (CWSU) at the Federal Aviation Administration (FAA) Air Route Traffic Control Center (ARTCC) in Anchorage, and other aviation interests (e.g. airline dispatch offices) upon request. KVERT also is responsible for alerting the Kamchatka Emergency Services Agency regarding any significant changes in volcanic activity. A generalized schematic illustrating the flow of information for KVERT is summarized in Fig. 5.

KVERT funding has been a mixture of basic Russian Academy of Sciences support from the host Institutes augmented on occasion by the local Kamchatka Administration, the International Air Transport Association, and the US Agency for International Development (USAID). The largest source of ongoing operational support has been the FAAR (Federal Aviation Authority of Russia), now called the Federal Unitary Enterprise State Air Traffic Management (ATM) Corporation of Russia, through its regional organization Kamchataeronavigatsia. During calendar year 2006, KVERT received $\sim \$ 23,000$ from the ATM Corporation; annual support has risen to $\$ 35,000$ in 2008 . These funds cover Institutional overhead, field, and laboratory equipment, partial support for seismic and other telemetry, data processing, telecommunications, and salary supplements for KVERT staff. Much of the scientific staff time for KVERT work is supported directly from IVS and KBGS.

Growth of the KVERT budget through time to allow for expanded monitoring has been limited, although some augmentation of monitoring networks has occurred through academic collaborations with US earth scientists (e.g. Ramsey and Dehn 2004; West et al. 2007; Carter et al. 2008). KVERT has had to suspend operations several times due to a lapse in operational funding, most recently for a month in the spring of 2007.

Formal agreements between the US FAA and the Russian FAAR reached at Russian American Coordinating Group for Air Traffic (RACGAT) meetings were instrumental in leveraging support for KVERT from the FAAR in the past. Additionally, ongoing advocacy by the International Civil Aviation Organization (ICAO), Air Line Pilots Association (ALPA), International Air Transport Association (IATA), and various airlines have been important in maintaining government funding for KVERT. 


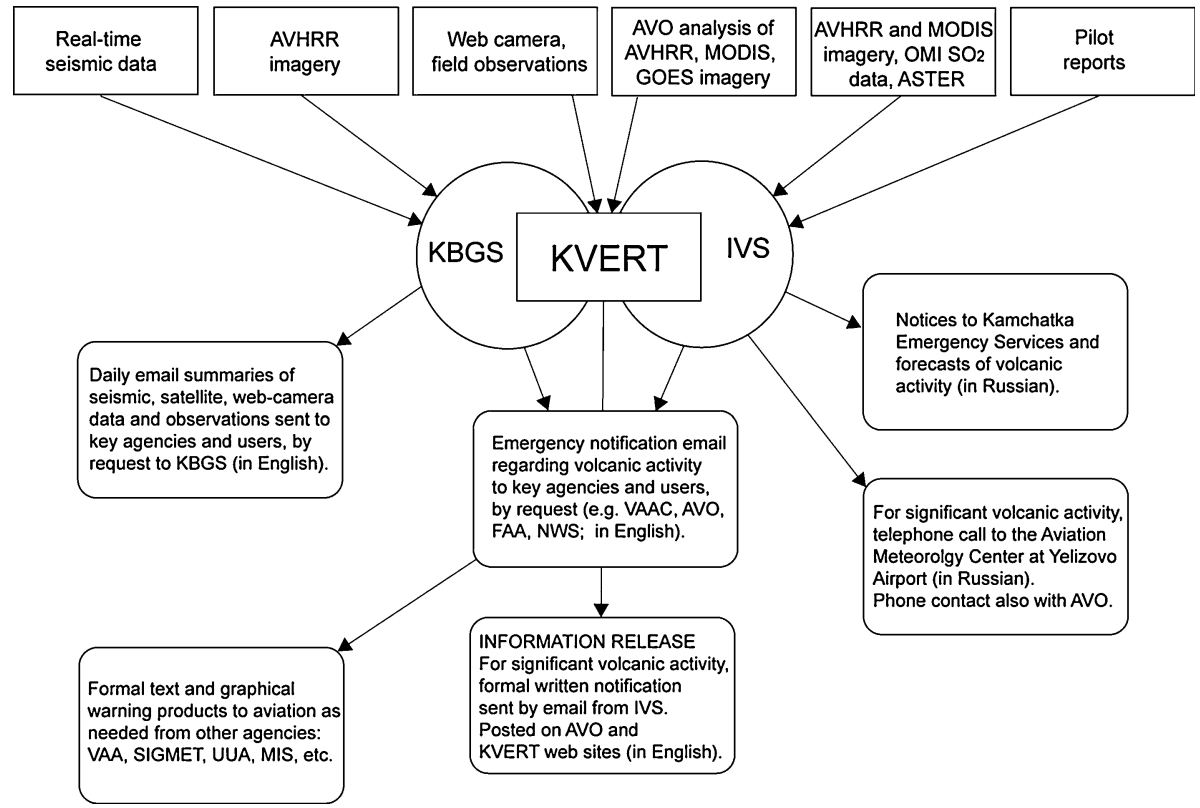

Fig. 5 Generalized information flow diagram for Kamchatkan volcanic activity

\section{Sakhalin Volcanic Eruption Response Team (SVERT)}

The Kurile Island chain stretches $1,250 \mathrm{~km}$ from the tip of Kamchatka to the island of Hokkaido in Japan (Fig. 6; Gorshkov 1970). At least 36 active volcanoes occur in this portion of the Pacific Rim, most on uninhabited, remote islands, but all are within $500 \mathrm{~km}$ of NOPAC air routes between North America and Asia (Neal et al. 2008a, b). In 1981, a significant explosive eruption from the northernmost Kurile island volcano, Alaid, produced an ash cloud that spread across a large area of Russian and US airspace in the North Pacific. A similar eruption today would severely impact the heavily travelled northern NOPAC routes as well as several of the busiest air routes within the Russian Far East. Recognizing that Kurile volcanoes presented a serious threat to aviation, KVERT and AVO colleagues met in Petropavlovsk and Yuzhno-Sakhalinsk in 2003 to discuss a Kurile volcano monitoring and eruption response team. The Institute of Marine Geology and Geophysics (IMGG), another Russian Academy of Sciences member based in YuzhnoSakhalinsk on the Island of Sakhalin, emerged as a logical home for this group. IMGG employs volcanologists, remote sensing specialists, and others experienced with the history and character of Kurile volcanoes. Following further discussions, IMGG announced the creation of SVERT in 2004 (Rybin et al. 2004). The mission of SVERT was to use all available and accessible monitoring data to detect and track activity at Kurile volcanoes, issue warning messages to aviation and other authorities, and to provide expert information about Kurile eruption histories and volcano behavior.

SVERT's monitoring program includes analysis of twice-daily NASA MODIS satellite imagery obtained from the ROSGEOLFOND (part of the Russian Ministry of Interior) in Yuzhno-Sakhalinsk. Only Alaid in the far north Kuriles is considered seismically monitored by a single real-time seismometer (and these data are telemetered to KBGS in 


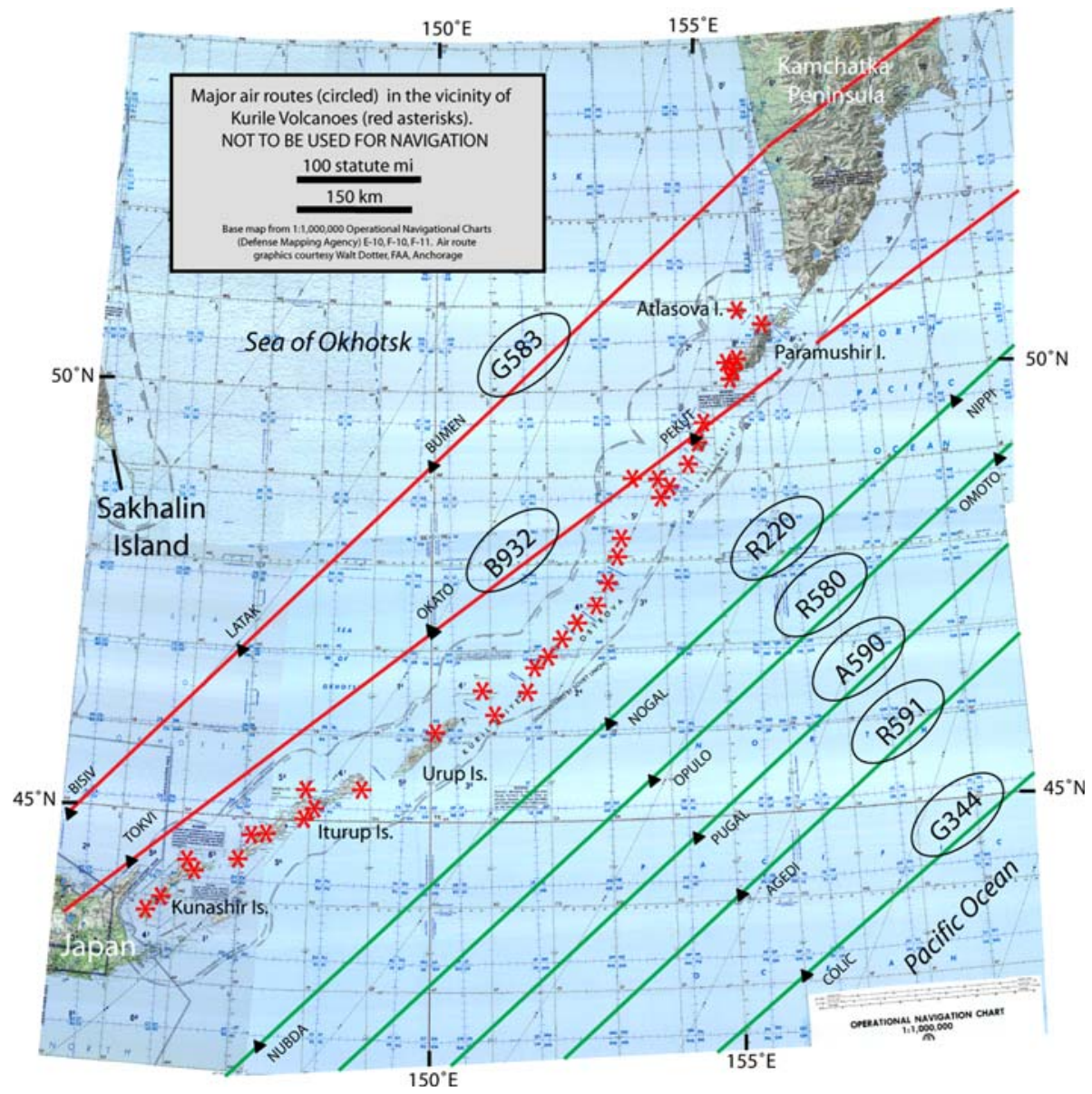

Fig. 6 Map of Kurile volcanoes (red asterisks) and approximate position of principal NOPAC (green) and RTE (red) air routes. Route names circled; triangles are air navigation fixes. See Figs. 1, 2

Petropavlovsk). Three regional seismic stations operated by the Sakhalin Experimental, and Methodical Seismological Department are located on Kunashir, Iturup, and Paramushir islands, but they are too far from volcanic centers to be useful in routine monitoring. Staff at seismic sites in Kurilsk and Yuzhno-Kurilsk on Iturup and Kunashir islands, respectively, can be contacted by telephone if activity is noted or suspected. Near-real-time earthquake plots from the University of Hokkaido in Japan that cover the southern Kurile region are consulted on occasion by SVERT staff via the Internet. Unfortunately, fieldintensive installation and telemetry for seismic monitoring networks on most of the remote Kuriles are prohibitively expensive at this time. Thus, SVERT relies nearly entirely on MODIS satellite monitoring with occasional ground-based reports from colleagues on the inhabited southern islands (Rybin et al. 2004). This lack of ground-based instrumentation means that at present, SVERT cannot confidently forecast eruptive activity by detecting precursory seismic or geodetic signals, nor will they receive instantaneous instrumental confirmation of an eruption in progress. 
Daily satellite summaries - similar to those prepared by KBGS for Kamchatka but including only analysis of MODIS images - are shared via email with KVERT and AVO staff who also scan available imagery of the Kurile region as part of daily monitoring duties (Rybin et al. 2004). SVERT has prepared a concise operational plan for responding to a detected eruption. Protocols include: (1) telephone notification of the Yuzhno-Sakhalinsk Air Traffic Control authority at the Yuzhno-Sakhalin airport to prompt an urgent pilot report; (2) email alerting of relevant VAACs, ARTCCs, CWSU, KVERT, and AVO; (3) Yuzhno-Sakhalinsk Meteorological Center is notified by fax and telephone to prompt issuance of a SIGMET; and (4) the Sakhalin Emergency Committee and administration of IMGG are notified by phone. AVO is prepared to post SVERT eruption messages on its web site and relay information to others as appropriate, in a manner similar to how AVO handles KVERT information. A summary of information flow for SVERT is in Fig. 7.

SVERT scientists also engage in volcanologic field work and related research under the auspices of IMGG. As such, they are the most knowledgeable source of information about past behavior and likely eruption styles for Kurile volcanoes. Despite an average of just under one eruption per year over the last century, Kurile volcanoes have been very quiet since SVERT began operation in 2004. Weak, possible steam and or gas explosions have been detected in MODIS imagery in 2004 (Neal et al. 2005) and again in 2006 (Neal et al.

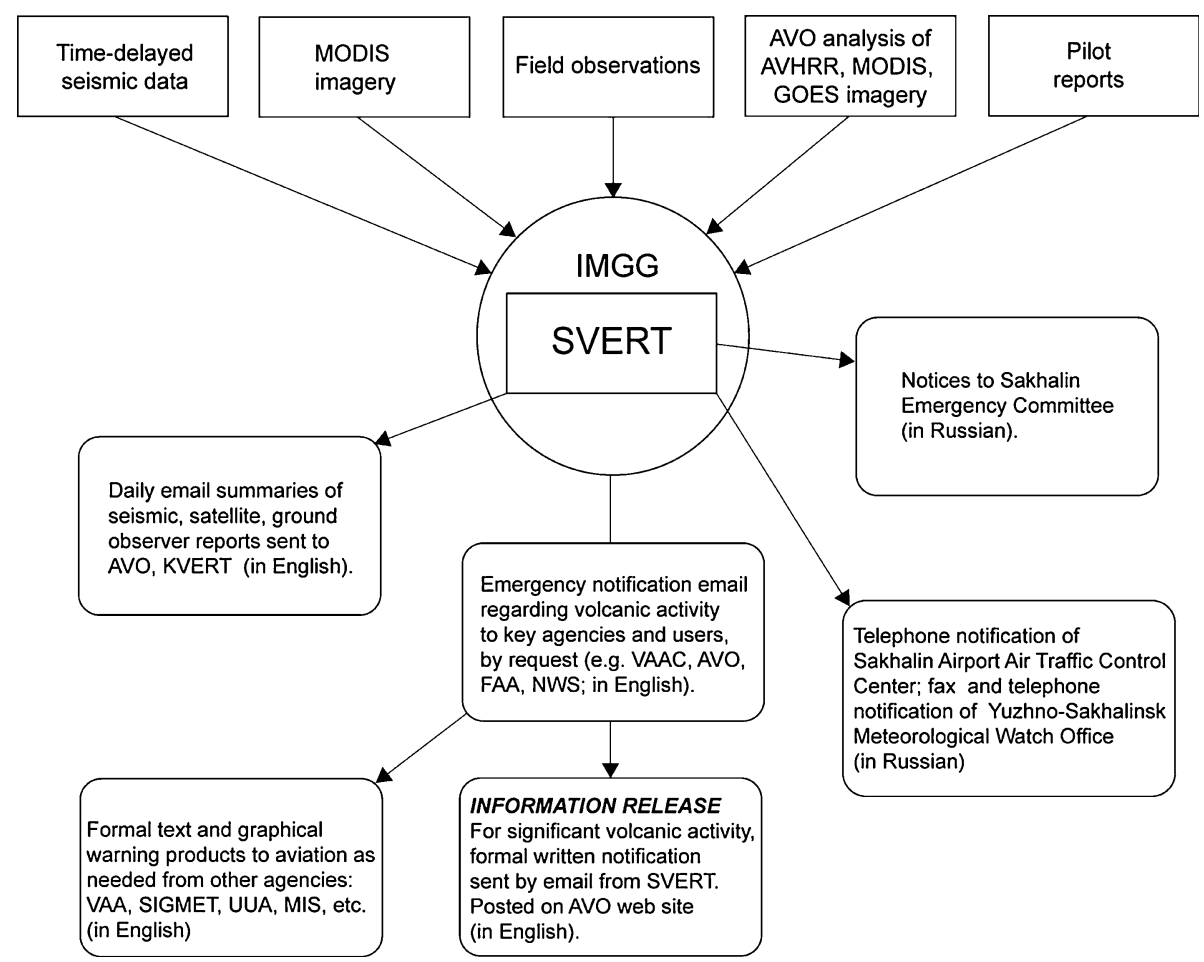

Fig. 7 Generalized SVERT information flow diagram for volcanic activity in the Kurile Islands; KVERT could also be the first to spot activity in the Kuriles and by agreement they will contact the MWO in Petropavlovsk and also SVERT in Sakhalin. KVERT is formally responsible for reporting activity on Paramushir and Atlasova Islands in the far northern Kuriles (see Figs. 2, 6) 
2008a, b). However, these events have been too minor and uncertain to have activated and tested communication protocols.

SVERT consists of several scientists who share daily satellite analysis and reporting duties. SVERT receives no supplemental funding from Russian aviation authorities and relies solely on base funding from its host Institute. A one-time assistance grant of $\sim \$ 18,000$ from the US Agency for International Development, Office of US Foreign Disaster Assistance through the USGS helped establish basic infrastructure of the SVERT team and communication protocols. SVERT leadership attended the 2004 International Symposium on Volcanic Ash and Aviation Safety (http://www.ofcm.noaa.gov/ICVAAS/ Proceedings2004/ICVAAS2004-Proceedings.htm) to learn operational details about global aviation and volcano hazards. SVERT staff members have visited AVO to learn about satellite volcano monitoring techniques and interagency coordination regarding aviation warnings. Despite persistent efforts by the SVERT director and allies at KVERT and AVO, securing funding for monitoring and reporting functions has been unsuccessful to date. Further, SVERT has also not been formally recognized as a State volcano observatory by the International Civil Aviation Organization (ICAO), a pre-requisite to applying for reimbursement of partial operational expenses as an air navigation service.

\section{Relationship with MWOs and ARTCCs}

Meteorological Watch Offices (MWOs) around the world are the primary, federal-level weather-agency entity charged with issuing a volcanic ash SIGMET, the formal notification of ash cloud hazard, location, and forecasted motion that is sent to the aviation industry during a volcanic eruption. Accordingly, volcano observatories worldwide must develop effective working relationships with MWOs. KVERT and the $24 \mathrm{~h}$ MWO located at Yelizovo International Airport adjacent to Petropavlovsk have established good lines of communication and protocols for interaction. The Yelizovo MWO shares pilot reports of volcanic activity with KVERT and usually coordinates with KVERT prior to the issuance of SIGMETs. The Yelizovo MWO is in direct contact with Petropavlovsk ARTCC who is responsible for issuing urgent pilot reports. KVERT notifies the MWO immediately by telephone if evidence of volcanic unrest or ash clouds is detected.

For Kurile eruptions, SVERT has worked to improve preparedness by developing a communication plan and educating MWO and ARTCC staff about Kurile volcanoes and likely eruption scenarios. Any Kurile eruption will likely involve coordination across adjacent air traffic control regions and both the Yuzhno-Sakhalinsk and the Petropavlovsk ARTCCs and MWOs (the line of demarcation occurs at 150E which bisects Urup Island in the southern Kuriles; Fig. 6). A Kurile eruption response exercise in late October 2007 highlighted key areas where additional pre-event coordination is needed. The authors recommend that this test be conducted periodically to maintain communication links and test procedures.

\section{Relationship with VAACs, Anchorage CWSU}

In 1993, ICAO, in cooperation with the World Meteorological Organization (WMO), established the requirement for Volcanic Ash Advisory Centers (VAACs) as part of the International Airways Volcano Watch Program. VAACs are responsible for providing formal international notification of the location and forecast motion of volcanic ash 
clouds for different regions of the planet. Under this framework, the Tokyo VAAC is responsible for ash clouds produced by Russian volcanoes in the Northern Pacific; Anchorage and Washington and Montreal VAACs are also involved if clouds propagate far enough to the east or south from Russian volcanoes, a common occurrence especially for larger eruptions. Communication among KVERT, SVERT, and these meteorological outlets is thus critical to providing timely and accurate warning messages for aviation.

To that end, the $24 \mathrm{~h}$ Tokyo VAAC office is notified immediately by email from both KVERT and SVERT upon detection of precursory volcanic unrest, verification of eruptions and ash clouds, or detection of seismicity that might indicate the presence of ash clouds. In addition to these alerts, Tokyo VAAC also utilizes Multi-Functional Transport Satellite (MTSAT) imagery (Oshima 2002) to detect ash clouds and issue notifications based on its own analysis. There is presently limited dialogue between Tokyo VAAC and KVERT or SVERT regarding volcano information to discuss and verify, for instance, potential ash clouds detected by the Tokyo VAAC. This is due in large part to language differences and the cost of telephone communications. With the extensive experience gained from ongoing eruptions in Kamchatka, however, the Tokyo VAAC is an effective, proactive, consistent source of Volcanic Ash Advisories (VAAs). To date, the Tokyo VAAC has not had to issue any advisories regarding Kurile activity.

The Anchorage and Washington VAACs and the Anchorage CWSU also receive email notification from KVERT regarding volcanic activity and will receive email alerts directly from SVERT when a Kurile event occurs. For redundancy, AVO contacts the Anchorage, Washington, and Montreal VAACs and the Anchorage CWSU by telephone for all Russian volcanic events of significance to aviation (usually ash suspected or confirmed above $6 \mathrm{~km}$ or 19,700 ft ASL). Finally, the Anchorage and Tokyo VAACs communicate with each other via facsimile to ensure coordination across VAAC boundaries.

\section{Interaction with the AVO}

Close collaboration among KVERT, SVERT, and AVO is necessary because of the common drift of Russian ash clouds toward and into US airspace. A formal agreement of operations between KVERT (its component Institutes KBGS and IVS) and AVO is revised periodically to outline roles and responsibilities. As of yet, there is no formal agreement between AVO and SVERT. All cooperative work between scientists of the US Geological Survey and the Russian Academy of Sciences is conducted under a formal Memorandum of Understanding between the US and Russian governments. As part of this relationship, AVO communicates with KVERT frequently (and with SVERT to a lesser degree) by email which has largely replaced phone calls as the primary means of contact. KVERT and SVERT staff are encouraged to call AVO, however, when significant changes in volcano status occur. AVO shares its twice-daily satellite analyses of Kamchatka and some Kurile volcanoes with Russian colleagues to provide additional sources of observations for the region. AVO staff can serve as the conduit for feedback from English-speaking aviation and meteorological authorities, and the airlines, in the aftermath of Russian eruptions. KVERT, SVERT, and AVO occasionally exchange personnel for organizational familiarization and training, discussion of the particular needs of aviation industry with regard to volcanic activity warnings, strategic planning, and collaborative research (West et al. 2007). 


\section{Examples of recent Russian eruption responses}

\subsection{Bezymianny May 2006}

One of the most active volcanoes of Kamchatka in recent decades, Bezymianny is famous for its March 30, 1956 catastrophic landslide, accompanying debris avalanche, and lateral blast (Gorshkov 1959; Bogoyavlenskaya et al. 1991). Since then, intermittent lava extrusion has produced a dome that periodically collapses generating pyroclastic flows and short-lived ash plumes (Carter et al. 2008). Importantly, the active lava dome tends to emit large amounts of thermal energy in the days to weeks prior to an explosive dome collapse event (Senyukov 2006; Carter et al. 2007). The May 2006 explosive event at Bezymianny, described below, is an excellent illustration of the use of satellite data in conjunction with seismic monitoring and a long term understanding of eruptive patterns to forecast a potentially dangerous ash cloud.

On April 7, 2006, after several months of low-level unrest, KVERT reported a new 'lava block' or spine extruding from a north-south fissure across the summit of the lava dome and indicated that the volcano was moving towards an explosive eruption. On May 3, KBGS staff shared a forecast of an eruption within the next 4 weeks citing increasing seismicity; this information was circulated internally among KBGS, IVS, and AVO staff by email. Based on this, KVERT formally announced an increased likelihood of explosive eruption within the next 4 weeks in an Information Release sent to the normal distribution list on May 5. Seismicity began to increase still further and on May 7, KVERT raised the level of concern color code to ORANGE and reported an increasing number of hot avalanches from the unstable dome. Fumarolic plumes containing ash rose above the summit and numerous shallow earthquakes were recorded under the volcano. Two days later, after the appearance of intermittent spasmodic tremor, a strong thermal anomaly, and a continuing high level of avalanche activity, KVERT declared level of concern color code $R E D$ and indicated that an explosive eruption was possible in the next several days.

The forecast was correct and on May 9, at 0821 UTC, an explosive eruption lasting $\sim 30$ min sent ash to $15 \mathrm{~km}$ above sea level. The ash cloud extended south-southeast and then later northeast from the volcano. Satellite images tracked this cloud for more than $500 \mathrm{~km}$. In response, the Alaska Aviation Weather Unit issued a series of SIGMETs and Tokyo VAAC issued seven Volcanic Ash Advisories. Several air carriers rerouted their planes to avoid the ash cloud. A pilot report of ash between an estimated 12-14 km ASL about $400 \mathrm{~km}$ west of Shemya in the far western Aleutian Islands was followed within a few hours by a National Weather Service ash fall advisory for the western Aleutians. The level of concern color code for Bezymianny reverted to ORANGE on May 10 and YELLOW on May 11 as seismicity returned to background levels and quiet effusion of lava likely resumed at the lava dome.

\subsection{Klyuchevskoy 2007}

Klyuchevskoy is another Kamchatka volcano that has repeatedly tested the Russian volcano warning system for aviation. A classic, symmetrical stratocone with a summit elevation of $4,750 \mathrm{~m}$, it is the highest of the active European and Asian volcanoes. Klyuchevskoy is frequently active with explosions and occasional lava flow production from the main vent in the steep-walled summit crater or from flank vents (Khrenov et al. 1991). Explosive eruptions have occurred in nearly every decade and at multiple times during most years since the early 1700s (Simkin and Siebert 1994). 
Following a vigorous phase of lava fountaining and explosions in January-March, 2005 (McGimsey et al. 2007), Klyuchevskoy Volcano remained at level of concern color code GREEN until seismicity began to increase in mid-December 2006. Based on this, KVERT elevated the volcano to YELLOW on December 19 where it remained through the end of the year and into 2007. Ash explosions, incandescence in the crater, intensive thermal anomalies in satellite imagery, and increasing seismicity prompted declaration of color code ORANGE on February 15, 2007. For the next several months, intermittent activity produced ash clouds that seldom rose above $6,500 \mathrm{~m}$; however, KVERT continued to warn of the possibility of a significant ash hazard. Daily emails described observed ash clouds, lava flows, and related activity.

On May 17, KVERT sent a formal notice of color code RED based on increasing amplitude of volcanic tremor and an observed ash plume to $10 \mathrm{~km}$ above sea level. Satellite data showed an ash cloud extending downwind more than $500 \mathrm{~km}$. Vigorous, nearly continuous ash producing eruptions lasted until early June when activity decreased slightly and KVERT reduced the level of concern to ORANGE. KVERT reinstated RED in late June when the intensity of ash production increased. Ash was subsequently reported over 9,500 $\mathrm{m}$ in altitude based on satellite temperature cloud top estimates on several occasions until early July. Substantial ash clouds, well imaged in satellite data when weather allowed, emanated from the volcano in nearly all directions over the course of this period of activity. KVERT daily messages and occasional formal Information Release statements contained critical observational details including status of the volcano, observations of ash clouds, and likely motion of the ash given current wind fields (Fig. 8).

During the course of this episode of Klyuchevskoy activity, dozens of aircraft scheduled to fly NOPAC transition routes chose to fly north or south of the Bering Sea to avoid ash. Tokyo and Anchorage VAACs and MWOs in Anchorage and Petropavlovsk issued a number of VAAs and SIGMETs and other aviation weather products (Figs. 9, 10). The

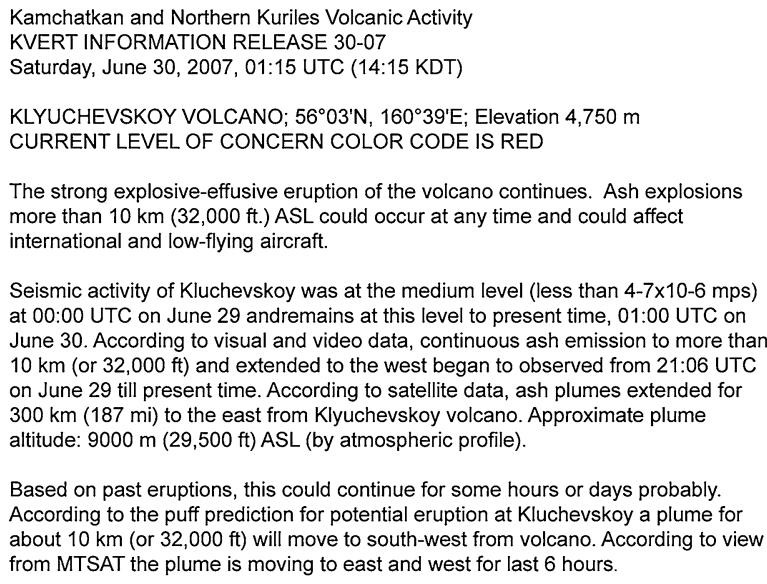

Fig. 8 Portion of a KVERT information release on June 30, 2007, describing ongoing activity and hazards from the Klyuchevskoy eruption. KVERT warning messages include the use of a Color Code to succinctly convey the level of concern regarding hazards and the intensity of activity at a particular volcano (Neal et al. 1997). First developed by the Alaska Volcano Observatory during the Mount Redoubt eruption in 19891990, US volcano observatories now use a slightly modified version of the color code (Gardner and Guffanti 2006). RED is the highest level of alert and indicates a significant eruption posing a hazard to aviation is either underway or expected 


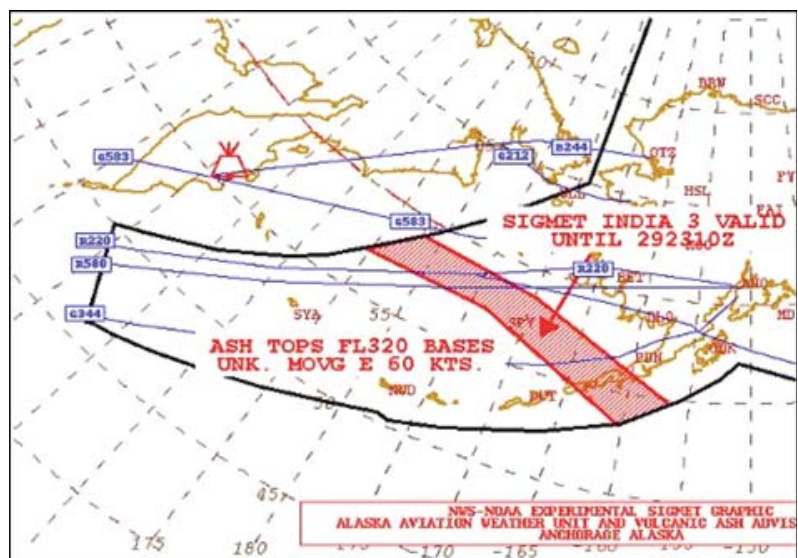

Fig. 9 Portion of a graphical SIGMET issued by the NWS Alaska Aviation Weather Unit in Anchorage on June 29, 2007, in response to a significant ash cloud produced by Klyuchevskoy Volcano in Kamchatka (volcano icon). Shown schematically are selected NOPAC and RFE air routes (blue lines). The red hachured area denotes airspace possibly affected by Klyuchevskoy ash. Text annotation indicates SIGMET identifier (India 3), expiration date and time, and specific details of the ash cloud (in this case, a cloud reaching flight level 320 or about 32,000 feet and moving east at 60 knots; the base of the cloud is unknown). The sharp demarcation of the impact areas with the Flight Information Region (FIR) boundary (black line) reflects adjoining areas of responsibility in Petropavlovsk, Oakland, and Tokyo ARTCCs. Graphical SIGMETs are considered an experimental product by NWS and are used as a visual supplement to the official text SIGMET

FVFE01 RJTD 291811
VOLCANIC ASH ADVISORY
ISSUED: $20070629 / 1811 Z$
VAAC: TOKYO
VOLCANO: KLIUCHEVSKOI 1000-26
LOCATION: N5603E16038
AREA: RUSSIA
SUMMIT ELEVATION: $4835 \mathrm{M}$
ADVISORY NUMBER: 2007/301
INFORMATION SOURCE: MTSAT-1R
AVIATION COLOUR CODE: NIL
ERUPTION DETAILS: ASH EMISSIONS CONTINUING.
OBS ASH DATE/TIME: 29/1659Z
OBS ASH CLOUD: UNKNOWN/FL320 N5602E16040-N5504E16243-N5704E16655-N565
7E17943-N5752E17945-N5800E16457-N5700E16038 MOV E 35KT
FCST ASH CLOUD +6 HR: 29/2259Z SFC/FL200 N5700E16130-N5700W18000-N553
0E18000-N5516E16127 FL200/350 N5702E15701-N5809E17624-N5830W16430-N55
00W16430-N5437E16600-N5500E15700
FCST ASH CLOUD +12 HR: 30/0459Z SFC/FL200 N5654E15840-N5619E17137-N57
30W17230-N5607W17238-N5353E17346-N5500E15830 FL200/350 N5324E15248-N5
657E15407-N5633E17207-N5900W15956-N4846W15212-N5541W16601-N5401E17827
FCST ASH CLOUD +18 HR: 30/1059Z SFC/FL200 N5610E15540-N5509W17928-N58
06W16634-N5227W17909-N5425E15507 FL200/350 N5554E15108-N5516E17312-N5
825W15727-N4408W14644-N5531W16303-N5312E17954-N5207E15030
NEXT ADVISORY: 20070630/0000Z
REMARKS: SOME PART OF THE ASH CLOUD IS IN THE RESPONSIBILITY AREA OF
VAAC ANCHORAGE. PLEASE ALSO SEE THE VAA FROM ANCHORAGE FOR THE CLOUD
IN THE EASTERN AREA.=

Fig. 10 VAA issued by the Tokyo Volcanic Ash Advisory Center on June 29, 2007, in response to ongoing ash production from Klyuchevskoy Volcano in Kamchatka. Note coordination with Anchorage VAAC mentioned in the last paragraph 


\section{PAZA ANCHORAGE (ARTCC)}

A0340/07 - VOLCANIC ADVISORY FOR KLYUCHEVSKOY VOLCANO, KAMCHATKAN PENINSULA, RUSSIA, 5603N16039E. EFFECTIVE IMMEDIATELY UNTIL FURTHER NOTICE. KLYUCHEVSKOY VOLCANO HAS BEEN IN AN ACTIVE STATE. HAZARDOUS EMISSIONS OF VOLCANIC ASH HAVE INTERMITTENTLY COMPLICATED AIR TRAVEL IN THE AREA. ANY IMPACT ON AIRCRAFT OPERATIONS IS DESCRIBED IN CURRENT SIGMET, CWA, OR PIREP INFORMATION. AIRCRAFT SHOULD REMAIN ALERT FOR POSSIBLE ASH CLOUDS AND REPORT ANY SIGHTINGS TO ATC. AIRCRAFT OPERATORS SHOULD CONTINUALLY EVALUATE OPERATIONS IN THE SIGMET AREA. AVIATION ALERT COLOR CODE RED IS IN EFFECT. FLIGHT INTO VOLCANIC ASH MAY CAUSE ENGINE DAMAGE/FAILURE AND ABRASION DAMAGE TO AIRFRAME AND WINDSHIELD SURFACES. ANY AIR CARRIERS, INCLUDING FOREIGN AIR CARRIERS THAT OBSERVE OR EXPERIENCE ANY DIFFICULTIES RESULTING FROM AN ENCOUNTER WITH VOLCANIC ASH, PLEASE NOTIFY ATC IMMEDIATELY IN ACCORDANCE WITH FAR 121.561 AND ICAO, ANNEX 3, PARAGRAPH 5.5 (SPECIAL AIRCRAFT OPERATIONS), AND ANNEX 6 PARAGRAPH 4.4.3 (HAZARDOUS FLIGHT CONDITIONS). CONTACT ANCHORAGE ARTCC, 907-269-1103, FOR ADDITIONAL INFO.

Fig. 11 Portion of an Advisory NOTAM issued by FAA in response to increased activity at Klyuchevskoy Volcano

FAA in Anchorage issued a special volcanic activity Notice to Airmen (NOTAM) to alert airlines to an ongoing volcanic hazard (Fig. 11) and the Anchorage ARTCC did receive several pilot reports of ash sightings over the Bering Sea. The exact number of flights impacted and total flight time lost to re-routing is not known. However, over the course of more than a month of significant ash cloud production, thousands of aircraft safely transited the Northern Pacific.

\section{Remaining challenges}

Despite significant improvements over the past 15 years, mitigation of airborne ash hazards to aviation in the Northern Pacific faces many ongoing challenges. These include a lack of sufficient and stable funding to ensure $24 / 7$ monitoring by Russian scientists familiar with eruptive behavior of Russian volcanoes. The absence of ground-based monitoring instrumentation on all but one Kurile volcano and many Kamchatkan volcanoes means that potentially dangerous eruptions could go unnoticed for many hours. Equipment and methodologies to validate eruption onset and determine ash-cloud heights (e.g. pressure sensors, radar, calibrated web-cameras) would substantially improve reliability and accuracy of warnings. Other non-technical challenges include an uneven awareness among international aviation users and officials regarding the risk, an unclear mandate within the host Russian scientific institutes to conduct applied hazard science and hazard communications, and language differences among Russian, Japanese, and US organizations with responsibility to issue warnings.

Solutions for many of these challenges are largely questions of policy, funding, and education. Those that are technical in nature could be solved in part by expanding scientistto-scientist collaboration on topics in volcanology, volcano monitoring, and hazard communications. A comprehensive regional review of volcano warning systems, available technology, training needs, and interagency communications would be a first step towards identifying the most important areas for attention as well as strategies for increasing support. This is especially critical given the frequency of ash cloud production in the 
region. From 2005 to 2007, Russian volcanoes generated an average of 2-3 ash clouds reaching $6 \mathrm{~km}$ above sea level or higher each month. Of these, most were produced by Klyuchevskoy Volcano whose summit elevation of 4,750 m means that ash eruptions can rapidly reach altitudes of concern to jet traffic.

A long-held tenet of volcano hazard mitigation is that local volcanologic expertise is essential to conduct effective monitoring and interpretation of volcanic unrest. Efforts over the past 15 years to develop this infrastructure in the Russian Far East with a capability to provide effective warnings to the aviation community have mostly succeeded as illustrated by the record of aviation safety during a time of frequent ash cloud production from Kamchatka. At the same time, international communication protocols among SVERT, KVERT, VAACs, MWOs, and other key players have evolved to keep pace with the increasing demand for rapid delivery of ash cloud warnings. Eruptions in the Russian Far East have international impacts and thus, international cooperation is required to effectively address these ongoing challenges.

Air traffic in the region is predicted to increase as more routes open over Russia and demand grows for commercial passenger and cargo flights around the Pacific Rim. Many segments of the NOPAC and other routes in the region span great distances over-water and far from alternate airfields, compounding the danger of an ash cloud encounter for the increasing number of twin-engine aircraft in the fleet mix. Together, these factors underscore the need to improve monetary support for Russian volcano monitoring efforts and to ensure that the inter- and intra-governmental procedures are ready to issue effective warnings. The need is especially acute for the under-monitored Kuriles where no significant eruption has occurred for more than two decades.

Acknowledgements The authors wish to acknowledge the many Russian, US, and Japanese volcanologists, meteorologists, air traffic controllers, and aviation managers who contribute to effective volcanic eruption warning systems in the Northern Pacific. Alexander Manevich of KVERT and IVS was particularly helpful in the early reviews of this document and in compiling data on Kamchatkan eruptions.

\section{References}

Airbus (2008) Global market forecast. http://www.airbus.com/en/corporate/gmf/. Accessed 1 December 2008

Bogoyavlenskaya GE, Braitseva OA, Melekestsev IV, Maksimov AP, Ivanov BV (1991) Bezymianny Volcano. In: Fedotov SA, Masurenkov Yu (eds) Active volcanoes of Kamchatka, vol 1. Nauka, Moscow, pp 195-197

Carter A, Ramsey M, Belousov A (2007) Detection of a new summit crater on Bezymianny Volcano lava dome: satellite and field-based thermal data. Bull Volcanol. doi:10.1007/s00445-007-0113-X

Carter AJ, Girina O, Ramsey MS, Demyanchuk YV (2008) ASTER and field observations of the 24 December 2006 eruption of Bezymianny Volcano, Russia. Remote Sens Environ. doi:10.1016/ j.rse.2007.12.001

Gardner CA, Guffanti MC (2006) U.S. Geological Survey's alert notification system for volcanic activity. US Geological Survey Fact Sheet 2006-3139, 4 pp

Gillespie A, Abrams M, Yamaguchi Y (2005) Scientific results from ASTER. Remote Sens Environ 99(1-2):1. doi:10.1016/j.rse.2005.05.014

Gorshkov GS (1959) Gigantic eruption of the Bezymianny Volcano. Bull Volcanol 20:77-109. doi: 10.1007/BF02596572

Gorshkov G (1970) Volcanism and the Upper Mantle: investigations in the Kurile Island Arc. Plenum, New York

International Airways Volcano Watch Operations Group (IAVWOG) (2008) Manual on volcanic ash, radioactive material and toxic chemical clouds, DRAFT incorporating Amendment 1: International 
Civil Aviation Organization Doc 9691. http://www.icao.int/anb/iavwopsg/Doc9691.pdf. Accessed 10 July 2008

Khrenov A, Dvigalo V, Kirsanov I, Fedotov S, Gorel'chik I, Zharinov N (1991) Klyuchevskoy Volcano. In: Fedotov S, Masurenkov Yu (eds) Active volcanoes of Kamchatka, vol 1. Nauka, Moscow, pp 146-163

Kirianov V, Neal C, Gordeev E, Miller T (2002) The Kamchatkan Volcanic Eruption Response Team (Kamchatkan Volcanic Eruptions Response Team). US Geological Survey Fact Sheet 064-02. http://geopubs.wr.usgs.gov/fact-sheet/fs064-02/

Levelt PF, Hilsenrath E, Leppelmeier GW, van den Oord GHJ, Bhartia PK, Tamminen J, de Haan JF, Veefkind JP (2006) Scientific objectives of the ozone monitoring instrument. IEEE Trans Geosci Remote Sens 44(5):1199-1208. doi:10.1109/TGRS.2006.872336

McGimsey R, Neal C (1996) 1995 Volcanic activity in Alaska and Kamchatka: summary of events and response of the Alaska Volcano Observatory. US Geological Survey Open-File Report OF 96-0738, 22 pp

McGimsey R, Neal C, Dixon J, Ushakov S, Rybin A (2007) 2005 Volcanic activity in Alaska, Kamchatka, and the Kurile Islands: summary of events and response of the Alaska Volcano Observatory. US Geological Survey Scientific Investigations Report 2007-5269, 94 pp

Miller T, Casadevall T (2000) Volcanic ash hazards to aviation. In: Sigurdsson H (ed) Encyclopedia of volcanoes. Academic Press, San Diego

Neal C (2003) Kamchatka volcanic eruption team celebrates tenth anniversary at workshop. EOS Trans AGU 84(41):427. doi:10.1029/2003EO410007

Neal C, Casadevall T, Miller T, Hendley J, Stauffer P (1997) Volcanic ash: danger to aircraft in the North Pacific. US Geological Survey Fact Sheet 030-97, 2 pp

Neal C, McGimsey R, Melnikov D (2005) 2004 Volcanic activity in Alaska and Kamchatka: summary of events and response of the Alaska Volcano Observatory. US Geological Survey Open-File Report 2005-1308, 67 pp

Neal CA, McGimsey RG, Dixon J, Manevich A, Rybin A (2008a) 2006 Volcanic activity in Alaska, Kamchatka, and the Kurile Islands: summary of events and response of the Alaska Volcano Observatory. US Geological Survey Scientific Investigations Report 2008-5214, 114 pp

Neal C, Rybin A, Chibisova M, Miller E (2008b) Active volcanoes of the Kurile Islands: a reference guide for aviation users. US Geological Survey Open-File Report 2008-1162, 10 pp. http://pubs.usgs.gov/of/ 2008/1162/

Oshima S (2002) MTSAT to be Japan's first hybrid spacecraft. Aviat Week Space Technol 157:26

Ramsey MS, Dehn J (2004) Spaceborne observations of the 2000 Bezymianny, Kamchatka eruption: the integration of high-resolution ASTER data into near real-time monitoring using AVHRR. J Volcanol Geotherm Res 135:127-146. doi:10.1016/j.jvolgeores.2003.12.014

Rybin A, Karagusov Y, Izbekov P, Terentyev N, Guryanov V, Neal C, Dean K (2004) Status of monitoring active volcanoes of the Kurile Islands: present and future. In: Proceedings of the second international conference on volcanic ash and aviation safety, Office of the Federal Coordinator for Meteorological Services and Supporting Research, Arlington, Virginia, 21-24 June 2004, pp 61-66

Senyukov S (2006) Algorithm of the eruption prediction of Bezymianny volcano (Kamchatka). In: proceedings of the 5th biennial workshop on subduction emphasizing the Japan-Kuril-KamchatkaAleutian arcs, University of Hokkaido, Sapporo, 14-19 July 2006, 57 pp

Simkin T, Siebert L (1994) Volcanoes of the world. Geoscience Press, Tucson

West M, Senyukov S, Chebrov V, Thelen W, Nikulin A, Buurman H (2007) Eruption seismicity of Bezymianny Volcano, Kamchatka, Russia. EOS Trans AGU 88(52), Fall Meeting Suppl Abstract S43A1034

Yamaguchi Y, Kahle AB, Tsu H, Kawakami T, Pniel M (1998) Overview of advanced spaceborne thermal emission and reflection radiometer (ASTER). IEEE Trans Geosci Rem Sens 36:1062-1071. doi: $10.1109 / 36.700991$ 